\title{
PENGARUH PEMBELAJARAN KOOPERATIF MELALUI MEDIA PERMAINAN ULAR TANGGA TERHADAP HASIL BELAJAR SISWA MATA PELAJARAN IPS DI SEKOLAH DASAR
}

\author{
Maya Kartika Sari \\ Prodi PGSD FIP IKIP PGRI MADIUN \\ mayakartika84@gmail.com
}

\begin{abstract}
Learning social studies in elementary dominated by the monotonous teaching methods, conventional and less effective, the teacher dominated learning, teaching by lecturing and recorded material, and using instructional media. This needs to be an improvement of learning. Researchers trying to implement cooperative learning methods through the media game of snakes and ladders as an attempt to create learning interesting, active, and can motivate student learning. This study aims to determine the effect of cooperative learning through the media cooperative game of snakes and ladders on learning outcomes of fourth grade students in academic year 2014/2015 Tembi Bantul. The study population was all students in fourth grade Tembi as experimental class and fourth grade students Bangeran as the control class. The samples were overall Tembi fourth grade students were 22 students and fourth grade students Bangeran as many as 11 students. This study design used quantitative research methods. Collecting data in this study used the test method. The test method used is the pre-test and post-test were given to the experimental group and the control group. Analysis of the data used is a statistical method t test (t-test). Results of the data analysis t test ( $t$-test $)$ obtained value $=12.7754$. At the significance level $(\alpha)=0.05$ earned value $=2.0441$. Then $t_{\text {hitung }} \geq t_{\text {tabe }}$ is $12,7754 \geq 2,0441$, then Ho is rejected and Ha accepted. The conclusion of this study was the influence of cooperative learning through the medium of snakes and ladders game on learning outcomes of students Subjects IPS in Tembi Bantul elementary school year 2014/2015.
\end{abstract}

Keywords : Cooperative Model, Media Snakes and Ladders, Learning Outcomes

\begin{abstract}
Abstrak
Pembelajaran IPS di SD didominasi oleh metode pembelajaran yang monoton, konvensional dan kurang efektif, yakni guru mendominasi pembelajaran, mengajar dengan berceramah dan mencatat materi, dan tidak menggunakan media pembelajaran. Hal ini perlu adanya perbaikan pembelajaran. Peneliti mencoba menerapkan metode pembelajaran kooperatif melalui media permainan ular tangga sebagai upaya untuk menciptakan pembelajaran yang menarik, aktif, dan dapat memotivasi belajar siswa. Penelitian ini bertujuan untuk mengetahui pengaruh metode pembelajaran kooperatif melalui media permainan ular tangga terhadap hasil belajar siswa kelas IV SD Tembi Bantul Tahun Pelajaran 2014/2015. Populasi penelitian ini adalah seluruh siswa kelas IV SD Tembi sebagai kelas experimen dan siswa kelas IV SD Bangeran sebagai kelas kontrol. Sampel penelitian adalah keseluruhan siswa kelas IV SD Tembi sebanyak 22 siswa dan siswa kelas IV SD Bangeran sebanyak 11 siswa. Penelitian ini menggunakan metode penelitian kuantitatif. Pengumpulan data menggunakan metode tes berupa pre-test dan post-test yang diberikan kepada kelompok eksperimen dan kelompok kontrol. Analisis data yang digunakan adalah metode statistik $t$ test (uji-t). Hasil analisis data $t$ test (uji-t) diperoleh nilai $=12,7754$. Pada taraf signifikansi $(\alpha)=0,05$ diperoleh nilai $=2,0441$. Maka $\mathrm{t}_{\text {hitung }} \geq \mathrm{t}_{\text {tabel }}$ yaitu $12,7754 \geq$ 2,0441, maka Ho ditolak. Kesimpulan dari hasil penelitian ini adalah ada pengaruh metode pembelajaran kooperatif melalui media permainan ular tangga terhadap hasil belajar siswa Mata Pelajaran IPS di SD Tembi Bantul tahun pelajaran 2014/2015.
\end{abstract}

Kata Kunci: Model Kooperatif, Media Ular Tangga, Hasil Belajar. 


\section{A. Pendahuluan}

Pembelajaran IPS di Sekolah Dasar memiliki kecendungan kearah kepasifan dan kekurang kondusifan, hal ini dikarenakan guru dalam mengajar masih bersifat konvensional. Pengajaran yang dilakukan hanya menggunakan metode ceramah dikolaborasi dengan tanya jawab sederhana mengenai materi yang dibahas, dan kurang memperhatikan kondisi, keaktivan, dan motivasi belajar siswa. Hal ini berdampak pada kekurangminatnya siswa dalam mengikuti pembelajaran IPS serta kejenuhan siswa dalam belajar.

Permasalahan tersebut juga terjadi di SD Tembi Kabupaten Bantul, dimana guru menjelaskan materi pelajaran dengan metode yang monoton dan kurang bervariasi, tidak adanya media pembelajaran yang memudahkan siswa dalam memahami materi, kepasifan siswa dalam pembelajaran, dan kurangnya motivasi siswa dalam belajar yang terlihat dari banyaknya siswa yang tidak berkonsentrasi dalam belajar dan bermain sendiri. Dampaknya hasil belajar siswa menjadi tidak maksimal. Hal ini perlu adanya perbaikan pembelajaran agar hasil belajar siswa menjadi meningkat.

Perbaikan pembelajaran yang dapat dilakukan oleh guru yakni dengan mengubah gaya mengajar, penggunaan metode pembelajaran yang tepat dan menyenangkan, dan pemanfaatan media pembelajaran yang menarik. Metode pembelajaran merupakan cara penyampaian guru dalam pembelajaran dalam rangka mencapai tujuan. Metode pemebalajran yang tepat dan menyenangkan dapat meningkatkan keaktivan, motivasi dan hasil belajar siswa. Sedangkan Media pembelajaran merupakan alat bantu yang dipergunakan guru untuk menyampaikan materi pelajaran kepada siswa. Media pembelajaran dapat berupa media grafis, media audio, media proyeksi diam, dan media permainan. Guru dapat menciptakan dan mengembangkan suatu media pembelajaran berbasis permainan bagi siswa. Penggunaan metode bembelajaran yang interaktif dan menyenangkan juga media pembelajaran yang manarik akan berpengaruh terhadap kegiatan siswa selama proses belajar mengajar

Berdasarkan uraian tersebut diatas, maka peneliti bermaksud untuk memberikan treatmen pembelajaran yakni dengan menggunakan metode belajar kooperatif melalui media permainan ular tangga untuk meningkatkan hasil belajar siswa.

\section{B. Kajian Pustaka dan Hipotesis Penelitian}

1. Kajian Teori

a. Metode Pembelajaran Kooperatif Menurut Slavin (dalam Isjoni, 2011: 15) "pembelajaran kooperatif adalah suatu model pembelajaran dimana siswa belajar dan bekerja dalam kelompok-kelompok kecil secara 
kolaboratif yang anggotanya 4-6 orang dengan struktur kelompok heterogen".

Menurut Etin Solihatin dan Raharjo (2007: 4) pada dasarnya cooperative learning mengandung pengertian sebagai suatu sikap bersama dalam struktur kerja sama yang teratur dalam kelompok, yang terdiri dari dua orang atau lebih dimana keberhasilan kerja sangat dipengaruhi oleh keterlibatan dari setiap anggota kelompok itu sendiri.

Pembelajaran kooperatif memiliki beberapa prinsip dalam pelaksanaannya, menurut Stahl, 1994 (dalam Etin Solihatin dan Raharjo, 2007: 6-9) menyebutkan prinsip-prinsip dasar dalam Cooperative Learning, adalah :

1) Perumusan tujuan belajar siswa harus jelas,

2) penerimaan menyeluruh oleh siswa tentang tujuan belajar,

3) ketergantungan yang sangat positif,

4) interaksi yang bersifat terbuka,

5) tanggung jawab individu,

6) kelompok bersifat heterogen,

7) interaksi sikap dan perilaku sosial yang positif,

8) tindak lanjut (follow up),

9) kepuasan dalam belajar.

Dari penjelasan diatas dapat disimpulkan bahwa pembelajaran kooperatif adalah suatu aktivitas pembelajaran yang menggunakan pola belajar siswa berkelompok untuk menjalinkerjasama dan saling ketergantungan positif sehingga tercapai proses dan hasil belajar yang produktif. Siswa yang belajar dengan model pembelajaran kooperatif akan memiliki motivasi yang tinggi karena didorong oleh rekan sebaya.

b. Media Pembelajaran Ular Tangga

Media pembelajaran adalah segala sesuatu yang dapat digunakan untuk menyalurkan pesan dari pengirim ke penerima sehingga dapat merangsang pikiran, perasaan, perhatian dan minat siswa sedemikian rupa sehingga terjadi proses belajar (Suwarna, 2005:126)

Media pembelajaran menurut Romiszowski (dalam Harjanto, 2005: 247) dinyatakan bahwa media pembelajaran

... as the carriers of massaes, from some transmitting source (with may be a human being or an intimate object), to the receiver of the massage (which is our case is the learner).

Menurut pendapat Romiszowski menyatakan bahwa media pembelajaran yakni penyampaian pesan (carriers of information) berinteraksi dengan siswa melalui pengindraannya siswa dapat dipanggil untuk menggunakan sesuatu alat indranya untuk menerima informasi, atau dapat juga menggunakan kombinasi alat indra sekaligus, sehingga kegiatan bekomunikasi lebih saksama.

Berdasarkan pendapat tersebut maka Media pembelajaran merupakan alat bantu yang dipergunakan guru untuk menyampaikan materi pelajaran kepada siswa dimana media pembelajaran akan memudahkan siswa dalam menerima pelajaran, siswa dapat terlibat langsung 
dalam proses pembelajaran dan menarik siswa untuk aktif dalam proses belajar.

Media pembelajaran dapat berupa media grafis, media audio, media proyeksi diam, dan media permainan. Guru dapat menciptakan dan mengembangkan suatu media pembelajaran berbasis permainan bagi siswa. Penggunaan media pembelajaran akan berpengaruh terhadap kegiatan siswa selama proses belajar mengajar. Pemilihan media pembelajaran harus disesuaikan dengan materi yang diajarkan dan kondisi siswa, sehingga diharapkan siswa dapat terlibat secara aktif dalam kegiatan pembelajaran. Seorang guru harus mampu memilih media pembelajaran yang tepat agar siswa dapat termotivasi untuk berperan aktif dalam pembelajaran.

Media pembelajaran yang dapat diciptakan oleh guru adalah permainan ular tangga. Permainan ular tangga dapat dijadikan sebagai media pembelajaran yang menyenangkan bagi siswa. Siswa akan cenderung tertarik mengikuti proses pembelajaran. Dalam hal ini, guru berperan sebagai fasilitator bagi siswa. Siswa yang aktif dalam permainan ular tangga dapat menemukan sendiri konsep materi yang sedang dipelajari. Sebab metode dalam permainan ular tangga dipadukan dengan diskusi kelompok. Dalam diskusi kelompok ini siswa diberikan suatu permasalahan yang berkaitan dengan materi dalam kehidupan sehari-hari.

c. Pembelajaran IPS di Sekolah Dasar

Ilmu Pengetahuan Sosial IPS menurut Moeljono Cokrodikardjo (dalam Maya Kartika, 2012:2) didefinisikan sebagai perwujudan suatu pendekatan interdisipliner dari ilmu sosial yang merupakan integritas dari berbagai ilmu sosial yakni sosiologi, antropologi budaya, psikologi, sejarah, geografi, ekonomi, ilmu politik dan ekologi manusia yang diformulasikan untuk tujuan instruksional dengan materi dan tujuan yang disederhanakan agar mudah dipahami.

Tujuan pembelajaran IPS menurut Jackson (2004) mengatakan bahwa :the purpose of sosial studies is to prepare youth for citizenship, there's also general agreement that the elements of a sound citizenship education are knowledge, skills, values, and participation. Sejalan dengan pendapat tersebut Cheft (1991) mengemukakan bahwa pembelajaran IPS berusaha membantu siswa dalam memecahkan permasalahan-permasalahan yang dihadapi, sehingga akan menjadikan semakin mengerti dan memahami lingkungan sosial masyarakatnya

Pendidikan IPS SD disajikan dalam bentuk synthetic science, karena basis dari disiplin ilmu ini terletak pada fenomena yang telah diobservasi di dunia nyata. Konsep, generalisasi, dan temuan-temuan penelitian dari synthetic 
science, ditentukan setelah fakta terjadi atau observasi dan tidak sebelumnya.

Pola pembelajaran IPS di SD hendaknya lebih menekankan pada unsur pendidikan dan pembekalan pemahaman, nilai-moral, dan keterampilan-keterampilan sosial pada siswa. Rancangan pembelajaran guru, hendaknya diarahkan dan di fokuskan sesuai dengan kondisi dan perkembangan potensi siswa agar pembelajaran yang dilakukannya benar-benar berguna dan bermanfaat bagi siswa. Pembelajaran Pendidikan IPS semestinya diarahkan pada upaya pengembangan iklim yang kondusif bagi siswa untuk belajar sekaligus melatih pengetahuan, sikap, nilai dan keterampilannya selama pembelajaran, disamping memungkinkan siswa untuk terlibat secara langsung dalam proses belajar mengajar.

d. Kajian Hasil Belajar

Hasil belajar adalah perubahan-perubahan yang terjadi pada diri siswa,baik yang menyangkut aspek kognitif, afektif, dan psikomotorik sebagai hasil dari kegiatan pembelajaran.Bloom (dalam Jihad dan Aris, 2012: 14) berpendapat bahwa hasil belajar dapat dikelompokkan ke dalam dua macam yaitu:

1) Pengetahuan terdiri dari empat kategori, yaitu;

a) Pengetahuan tentang fakta b) Pengetahuan tentang posedural

c) Pengetahuan tentang konsep

d) Pengetahuan tentang prinsip

2) Keterampilan juga terdiri dari empat kategori, yaitu:

a) Keterampilan untuk berfikir atau keterampilan kognitif

b) Keterampilan untuk bertindak atau keterampilan motorik

c) Keterampilan bereaksi atau bersikap

d) Keterampilan berinteraksi

Untuk memperoleh hasil belajar, dilakukan evaluasi atau penilaian yang merupakan tindak lanjut atau cara untuk mengukur tingkat penguasaan siswa. Kemajuan prestasi belajar siswa tidak saja diukur dari tingkat penguasaan ilmu pengetahuan tetapi juga sikap dan keterampilan. Dengan demikian penilaian hasil belajar siswa mencakup segala hal. Hasil belajar sebagaimana telah dijelaskan di atas meliputi pemahaman konsep konsep (aspek kognitif), keterampilan proses (aspek psikomotorik), dan sikap siswa (aspek afektif)

2. Kerangka Berpikir

Pembelajaran IPS disekolah lebih banyak didominasi oleh guru dan menggunakan metode pembelajaran yang konvensional. Pembelajaran IPS yang memuat hafalan-hafalan materi yang menuntut guru untuk mengejar target materi yang harus diajarkan sehingga guru terkadang menyampaikan materi hanya dengan berceramah dan mencatat saja. Hal ini menimbulkan kebosanan dan kejenuhan siswa dalam belajar, sehingga hasil belajar siswa tidak maksimal. 
Berdasarkan permasalahan diatas perlu adanya perbaikan pembelajaran agar hasil belajar mata pelajaran IPS menjadi meningkat, yakni dengan penerapan variasi metode dan media pembelajaran. Salah satu metode pembelajaran yang dapat mengaktifkan siswa yakni metode kooperatif. Dengan metode kooperatif siswa dapat terlibat langsung dalam pembelajaran, siswa dapat bekerjasama dan saling percaya dengan teman, dan keaktifan siswa menjadi lebih baik. Metode kooperatif pada penelitian ini menggunakan media permainan ular tangga, dimana dibutuhkan kolaborasi yang baik antar siswa dalam rangka menyelesaikan permainan. Permainan ular tangga merupakan media pembelajaran yang interaktif dan menarik, dapat memecahkan kejenuhan belajar dan siswa dapat memahami materi lebih baik. Harapannya melalui metode kooperatif berbantu media permainan ular tangga dapat meningkatkan hasil belajar siswa kelas IV SD Ngoto Bantul.

Berikut ini kerangka berfikir pengaruh Metode Pembelajaran Kooperatif Melalui Media Permainan Ular Tangga Terhadap Hasil Belajar Siswa kelas IV pada mata pelajaran IPS.

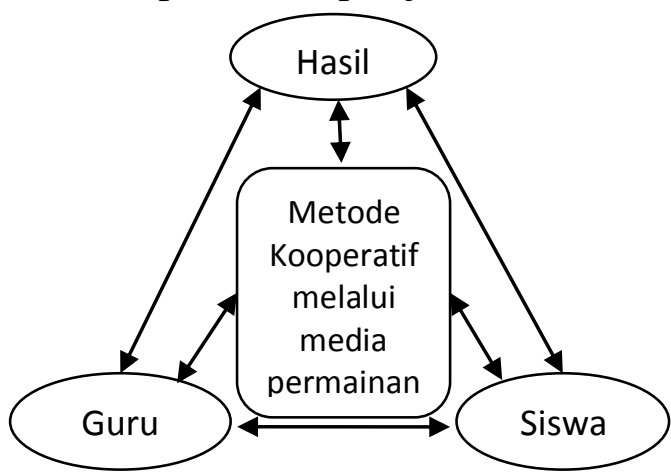

Gambar1. Kerangka Berfikir

3. Hipotesa penelitian

Hipotesa berupa dugaan sementara terhadap hasil penelitian. Berdasarkan permasalahan diatas maka dirumuskan Hipotesa dalam penelitian ini yakni ;

Ho $=$ Tidak ada pengaruh Metode Pembelajaran Kooperatif Melalui Media Permainan Ular Tangga Terhadap Hasil Belajar Siswa Mata Pelajaran IPS di SD Tembi Bantul Tahun Pelajaran 2014/2015

$\mathrm{Ha}=$ Ada pengaruh Metode Pembelajaran Kooperatif Melalui Media Permainan Ular Tangga Terhadap Hasil Belajar Siswa Mata Pelajaran IPS di SD Tembi Bantul Tahun Pelajaran 2014/2015

Hipotesa ini akan terbukti melalui penelitian yang akan dilakukan melalui uji hipotesa berdasarkan hasil penelitian.

\section{Metode Penelitian}

1. Setting Penelitian

Penelitian ini dilaksanakan di SD Tembi dan SD Bangeran Kabupaten Bantul. Waktu penelitian 2 bulan yakni pada bulan Maret 2015 sampai April 2015 dengan tahapan pengajuan proposal, pengumpulan data, pengolahan data dan pembuatan laporan akhir penelitian.

2. Rancangan Penelitian

a. Metode Penelitian 


Metode penelitian ini
menggunakan
eksperimen untuk metode
pengaruh perlakuan tertentu
terhadap yang lain dalam
kondisi terkendalikan. penelitian
tersebut dilakukan dengan baik,
maka dapat menjawab hipotesis
yang utamanya berkaitan
dengan hubungan sebab akibat
serta berapa besar hubungan
sebab akibat tersebut dengan
cara memberikan perlakuan-
perlakuan tertentu pada
kelompok eksperimen dan
menyediakan kontrol untuk
perbandingan

b. Desain Penelitian

$$
\text { Desain penelitian }
$$
menggunakan Pre-Test-PostTest Control Group Design. Dimana terdapat dua kelompok yaitu kelompok eksperimen dan kelompok kontrol atau pembanding. Kelompok pertama diberi perlakuan (X) yang disebut kelompok eksperimen dan kelompok yang lain tidak diberi perlakuan yang disebut kelompok pembanding atau kelompok kontrol (Y). Kedua kelompok ini diberi pengukuran yang sama yaitu Pretest (tes sebelum pembelajaran) dan Posttest (tes setelah pembelajaran).

c. Variabel Penelitian

Dalam penelitian ini terdapat dua variabel yaitu variabel bebas dan variabel terikat. Variabel bebas dalam penelitian ini adalah metode pembelajaran kooperatif melalui media permainan ular tangga. Sedangkan Variabel terikat dalam penelitian ini adalah hasil belajar siswa kelas IV pada mata pelajaran IPS

3. Data dan cara pengumpulan data

a. Sumber dan jenis data

Sumber data dari penelitian ini adalah populasi siswa kelas IV di SD Tembi (kelas Experimen) sebanyak 22 orang, dan siswa kelas IV SD Bageran (kelas kontrol) Sebanyak 11 orang. Sampel dalam penelitian ini yakni siswa kelas IV SD Tembi (kelas Experimen) sebanyak 22 orang dan siswa kelas IV SD Bageran (kelas kontrol) sebanyak 11 orang. Teknik pengambilan sampel yakni menggunakan teknik sample jenuh yakni keseluruhan dari populasi diambil untuk dijadikan sampel penelitian.

Jenis data pada penelitian ini adalah data kuantitatif, yakni peneliti melakukan pengukuran menggunakan angka kemudian mendeskripsikan hasil penelitian yang telah didapatkan.

b. Teknik pengambilan data

Metode pengumpulan data yang digunakan dalam penelitian ini adalah teknik tes. Tes yang digunakan adalah pretest dan posttest yang diberlakukan sama antara kelas kontrol dan kelas eksperimen, namun dengan metode yang berbeda.

Tes yang digunakan dalam penelitian ini telah dilakukan uji 
validitas dan reliabelitas terhadap soal yang akan diberikan kepada siswa. Berdasarkan hasil uji validitas yang dilakukan terhadap instrumen tes yakni terdapat 22 soal yang valid sehingga peneliti menggunakan 20 soal untuk diberikan kepada siswa, sedangkan hasil reliabelitas instrumen tes diperoleh nilai $>$ yaitu $0,937>0,576$, maka tes dikatakan reliabel. Ini berarti instrumen tes hasil belajar tersebut reliabel, sehingga dapat digunakan untuk mengetahui tingkat hasil belajar siswa.

c. Teknik Analisa Data

Data dalam penelitan ini melalui uji normalitas dan uji homogenitas. Uji normalitas menggunakan metode lilliefors dengan taraf signifikansi $(\alpha)$ sebesar 0,05, dan uji homogenitas menggunakan uji F. Setelah itu dilakukan uji hipotesis apabila seluruh komponen penelitian telah diuji keabsahannya. Tujuan untuk mengetahui pengaruh metode pembelajaran kooperatif melalui media permainan ular tangga terhadap hasil belajar siswa kelas IV pada mata pelajaran IPS di SD Tembi Bantul. Data ini bersifat data interval. Untuk mengukur data interval dan terdapat kelompok eksperimen dan kelompok kontrol, maka analisis data menggunakan statistik dengan rumus " $t$ " test. Rumus

"t" test yang digunakan adalah:

$$
t=\frac{\overline{x_{1}}-\overline{x_{2}}}{s_{g a b} \sqrt{\frac{1}{n_{1}}+\frac{1}{n_{2}}}}
$$

Langkah analisa data yang dilakukan peneliti yakni menulis $\mathrm{H}_{\mathrm{a}}$ dan $\mathrm{H}_{\mathrm{o}}$ dalam bentuk kalimat dan angka statistik, menghitung nilai t tes, menentukan taraf signifikan $\alpha=95 \%$ atau $99 \%$, mencari $t_{\text {tabel }}$ dengan pengujian dua pihak dimana $\mathrm{dk}=\mathrm{n}_{1}+$ $\mathrm{n}_{2}-2$, menentukan kriteria pengujian yakni Ha diterima jika $t_{\text {hitung }}>t_{\text {tabel, }}$, membandingkan $t_{\text {hitung }}$ dengan $t_{\text {tabel, }}$, dan membuat kesimpulan. Dengan menggunakan uji t tersebut akan dapat diketahui hasil penelitian dikelas kontrol dan kelas eksperimen, sehingga peneliti dapat menyimpulkan hasil penelitian yang relevan.

\section{Hasil Penelitian dan Pembahasan}

\section{Deskripsi Data}

Data yang disajikan pada penelitian ini adalah data tes yakni pretest dan posttest siswa kelas IV SD Tembi setelah mendapat perlakuan dengan metode pembelajaran kooperatif melalui media permainan ular tanggadan SD Bageran setelah mendapat perlakuan dengan metode pembelajaran konvensional. Berikut akan dijelaskan data pretest dan posttest tersebut yaitu:

a. Data Pre-tes Hasil Belajar IPS (sebelum mendapat perlakuan) di kelas kontrol dan experimen

Data nilai Pre-test hasil belajar IPS adalah data keadaan awal sebelum 
mendapat perlakuan yang diperoleh dari nilai pre-test hasil belajar pada kelas IV SDTembi (kelas eksperimen) dan kelas IV SD Bageran (kelas kontrol). Berdasarkan data nilai pre-test hasil belajar IPS siswa kelas eksperimen dan kelas kontrol menunjukkan bahwa kelas IV SDTembi (kelas eksperimen) dari 22 siswa diperoleh nilai tertinggi sebesar 90, nilai terendah 55 dengan rata-rata sebesar 73,86 ; median (nilai tengah) sebesar 77,5 ; modus (nilai yang sering muncul) sebesar 80 dan standar deviasi sebesar 9,75.

Pada siswa kelas IV SD Bageran (kelas kontrol) dari 11 siswa diperoleh nilai tertinggi sebesar 95, nilai terendah sebesar 60 dengan rata-rata sebesar 76,82; median (nilai tengah) sebesar 75 ; modus (nilai yang sering muncul) sebesar 85 dan standar deviasi sebesar 11,24.

Gambaran lebih jelas mengenai data nilai pre-test hasil belajar IPS siswa kelas IV SDTembi (kelas eksperimen) dan kelas IV SD Bageran (kelas kontrol) dapat dilihat pada tabel nilai pre-test hasil belajar IPS yakni:

Tabel. 1. Hasil nilai Pre-tes

\begin{tabular}{lcc}
\hline \multirow{2}{*}{ Hasil } & \multicolumn{2}{c}{ Pre test hasil belajar } \\
\cline { 2 - 3 } & $\begin{array}{c}\text { Kelas } \\
\text { experimen }\end{array}$ & $\begin{array}{c}\text { Kelas } \\
\text { kontrol }\end{array}$ \\
\hline N(jumlah siswa) & 22 & 11 \\
\hline $\begin{array}{l}\mathrm{X}_{\text {maks }} \text { (Skor } \\
\text { maksimal) }\end{array}$ & 90 & 95 \\
\hline
\end{tabular}

\begin{tabular}{lcc}
\hline $\begin{array}{l}\mathrm{X}_{\min } \text { (Skor } \\
\text { minimal) }\end{array}$ & 55 & 60 \\
\hline (Rata - rata) & 73,86 & 76,82 \\
\hline $\begin{array}{l}\text { S(simpangan } \\
\text { baku) }\end{array}$ & 9,75 & 11,24 \\
\hline
\end{tabular}

b. Data post tes Hasil Belajar IPS (setelahmendapat perlakuan) di kelas kontrol dan experimen

Pemberian post-test hasil belajar IPS dilakukan setelah siswa kelas IV SDTembi mendapatkan perlakuan berupa metode pembelajaran kooperatif melalui media permainan ular tangga dan kelas IV SD Bageran dengan model pembelajaran yang digunakan oleh guru sehari-hari yaitu konvensional.Berdasarkan nilai post-test menunjukkan bahwa kelas IV SD Tembi (kelas eksperimen) dari 22 siswa diperoleh nilai tertinggi sebesar 100, nilai terendah 70 dengan rata-rata sebesar 81,82, median (nilai tengah) sebesar 82,5, modus (nilai yang sering muncul) sebesar 85 dan standar deviasi sebesar 9,20.

Pada siswa kelas IV di SD Bageran (kelas kontrol) dari 11 siswa diperoleh nilai tertinggi sebesar 85 , nilai terendah sebesar 50 dengan rata-rata sebesar 66,82 median (nilai tengah) sebesar 65, modus (nilai yang sering muncul) sebesar 80 dan standar deviasi sebesar 12,70 .

Gambaran lebih jelas mengenai data nilai post-test hasil belajar IPS siswa kelas IV SDTembi (kelas eksperimen) dan kelas IV SD Bageran (kelas kontrol) dapat dilihat pada tabel nilai post-test hasil belajar IPS berikut ini: 
Tabel. 2. Hasil nilai Post-tes

\begin{tabular}{lcc}
\hline \multirow{2}{*}{ Hasil } & \multicolumn{2}{c}{ Post-test hasil belajar } \\
\cline { 2 - 3 } & $\begin{array}{c}\text { Kelas } \\
\text { experimen }\end{array}$ & $\begin{array}{c}\text { Kelas } \\
\text { kontrol }\end{array}$ \\
\hline $\mathrm{N}$ (jumlah siswa) & 22 & 11 \\
\hline $\begin{array}{l}X_{\text {maks }} \text { (Skor } \\
\text { maksimal) }\end{array}$ & 100 & 85 \\
\hline$X_{\min }$ (Skor minimal) & 70 & 50 \\
\hline (Rata - rata) & 81,82 & 66,82 \\
\hline S(simpangan baku) & 9,20 & 12,70 \\
\hline
\end{tabular}

c. Perhitungan Pretest dan Posttest Kelompok Eksperimen dan Kontrol

Berdasarkan pengolahan data pretest dan posttest siswa kelas IV pada mata pelajaran IPS dengan menggunakan metode pembelajaran kooperatif melalui media permainan ular tangga (kelas eksperimen) dan menggunakan metode pembelajaran konvensional (kelas kontrol). Maka diperoleh hasil pengolahan data sebagai berikut:

Tabel 3. Hasil Pengolahan Nilai Pretest dan Posttest

\begin{tabular}{lcccc}
\hline \multirow{2}{*}{ Hasil } & \multicolumn{3}{c}{ Kelas } & \multicolumn{3}{c}{ Kelas Kontrol } \\
\cline { 2 - 5 } & $\begin{array}{l}\text { Pre- } \\
\text { Test }\end{array}$ & $\begin{array}{c}\text { Post- } \\
\text { Test }\end{array}$ & $\begin{array}{c}\text { Pre- } \\
\text { Test }\end{array}$ & $\begin{array}{c}\text { Post- } \\
\text { Test }\end{array}$ \\
\hline $\begin{array}{l}\text { N(jumlah } \\
\text { siswa) }\end{array}$ & 22 & 22 & 11 & 11 \\
\hline $\begin{array}{l}X_{\text {maks }}(\text { Skor } \\
\text { maksimal) }\end{array}$ & 90 & 100 & 95 & 85 \\
\hline $\begin{array}{l}X_{\text {min }}(\text { Skor } \\
\text { minimal) }\end{array}$ & 55 & 70 & 60 & 50 \\
\hline $\begin{array}{l}\text { (Rata - rata) } \\
\text { (Rata }\end{array}$ & 73,86 & 81,82 & $\begin{array}{c}76,8 \\
2\end{array}$ & 66,82 \\
\hline $\begin{array}{l}\text { S(simpangan } \\
\text { baku) }\end{array}$ & 9,75 & 9,20 & $\begin{array}{c}11,2 \\
4\end{array}$ & 12,70 \\
\hline
\end{tabular}

Dari data diatas dapat dilihat bahwa siswa yang menggunakan metode pembelajaran kooperatif melalui media permainan ular tangga mempunyai nilai rata-rata pretest 73,86 dengan nilai maksimal 90 serta minimal 55 dan nilai rata-rata posttest 81,82 dengan nilai maksimal 100 serta nilai minimal 70 .

Sedangkan siswa yang diajar dengan menggunakan model pembelajaran konvensional mempunyai nilai rata-rata pretest 76,82 dengan nilai maksimal 95 serta minimal 60 dan nilai rata-rata posttest 66,82 dengan nilai maksimal 85 serta nilai minimal 50 .

Berdasarkan pernyataan diatas, dapat disimpulkan bahwa rata-rata nilai tes IPS siswa kelas eksperimen lebih baik dibandingkan rata-rata nilai pada kelas kontrol. Hal ini berarti hasil tes belajar pada kelas eksperimen yang menggunakan metode pembelajaran kooperatif melalui media permainan ular tangga lebih baik dibandingkan hasil tes belajar pada kelas kontrol yang hanya menggunakan metode pembelajaran konvensional.

\section{Analisa Data}

Analisis data dilakukan untuk menguji kebenaran hipotesis yang diajukan dalam penelitian ini yaitu ada pengaruhpenggunaan

metodepembelajaran kooperatif melalui media permainan ular tangga pada mata pelajaran IPS terhadap hasil belajar siswa kelas IVdi SD Tembi dan siswa kelas IV di SD Bangeran tahun pelajaran 2014/2015.

Untuk mengetahui kebenaran hipotesis ini maka penulis 
membandingkan hasil belajar belajar IPS siswa kelas eksprimen yang menggunakan metode pembelajaran kooperatif melalui media permainan ular tangga dan kelas kontrol yang menggunakan metode pembelajaran konvensional. Sebelum membuktikan hipotesis, langkahlangkah yang terlebih dahulu dilakukan adalah melakukan uji normalitas dan uji homogenitas.

a) Hasil Analisis Uji Normalitas

Uji normalitas digunakan untuk mengetahui apakah data sampel tersebut berasal dari populasi yang berdistribusi normal atau tidak. Pada penelitian ini, uji normalitas dihitung dengan menggunakan metode lilliefors dengan taraf signifikansi $(\alpha)$ sebesar 0,05 (penghitungan selengkapnya dapat dilihat pada lampiran 10. Kriteria ujinya sebagai berikut:

- $\mathrm{H}_{0}$ diterima jika Lobs $\leq$ Ltabel

- $\mathrm{H}_{0}$ ditolak jika Lobs > Ltabel

Hasil uji normalitas Lilifors untuk kelas IVdi SD Tembi (kelas eksperimen) dengan tingkat $\alpha=$ 0,05 menunjukkan bahwa nilai koefisien $L=0,13651 \leq$ Ltabel =0,249, Ini berarti Ho diterima, sehingga dapat disimpulkan bahwa data sampel untuk kelas eksperimen berasal dari populasi yang berdistribusi normal.

Uji normalitas Lilifors untuk kelas IV di SD Bangeran (kelas kontrol) dengan tingkat $\alpha=$
0,05 menunjukkan bahwa niliai koefisien $L=0,19327 \leq$ Ltabel $=0,249$. Ini berarti Ho diterima, sehingga dapat disimpulkan bahwa data sampel untuk kelas kontrol berasal dari populasi yang berdistribusi normal.

b) Hasil Analisis Uji Homogenitas

Uji homogenitas digunakan untuk mengetahui apakah sampel data pengamatan kelompok eksperimen dan kontrol memilikivariansi yang homogen. Hasil analisis uji homogenitas pre-test dengan uji $\mathrm{F}$ pada tingkat signifikansi $\alpha$ $=0,05$ menunjukkan bahwa $\mathrm{F}$ hitung $\leq \mathrm{F}$ tabel atau $1,33 \leq 3,31$. Sedangkan hasil analisis uji homogenitas post-test dengan uji $\mathrm{F}$ pada tingkat signifikansi $\alpha=0,05$ menunjukkan bahwa $\mathrm{F}$ hitung $\leq \mathrm{F}$ tabel atau $1,91 \leq 3,31$. Ini berarti Ho diterima, sehingga dapat disimpulkan bahwa data sampel kedua kelompok homogen.

c) Hasil Analisis Uji Hipotesis

Dalam penelitian ini uji hipotesis yang digunakan adalah uji t. Uji t tersebut digunakan untuk mengetahui apakah ada pengaruh metode pembelajaran kooperatif melalui media permainan ular tangga terhadap hasil belajar IPS siswa kelasIVdi SD Tembi Bantul tahun ajaran 2014/2015. Uji hipotesis pada penelitian ini menggunakan uji $\mathrm{t}$ dengan varian homogen dan tingkat signifikasi 5\%, kriteria ujinya sebagai berikut:

$\mathrm{H}_{1}$ diterima jika $\mathrm{t}_{\text {hitung }}>\mathrm{t}_{\text {tabel }}$

$\mathrm{H}_{1}$ ditolak jika $\mathrm{t}_{\text {hitung }}<\mathrm{t}_{\text {tabel }}$

Keterangan:

$\mathrm{H}_{\mathrm{o}}: \mu_{1}=\mu_{2} \quad$ (Tidak ada pengaruh metode pembelajaran kooperatif melalui media permainan ular tangga terhadap 
hasil belajar IPS siswa kelasIVdi SD Tembi Bantul tahun ajaran 2014/2015).

$\mathrm{H}_{1}: \mu_{1} \neq \mu_{2} \quad$ (Ada pengaruh metode pembelajaran kooperatif melalui media permainan ular tangga terhadap hasil belajar IPS siswa kelasIVdi SD Tembi Bantul tahun ajaran 2014/2015).

Berdasarkan hasil analisis data, diperoleh $t_{\text {hitung }}=12,7754$ dan $t_{\text {tabel }}=2,0441$. Karena $t_{\text {hitung }}>$

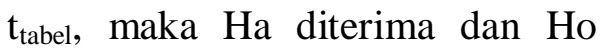
ditolak. Kesimpulannya bahwa ada pengaruh metode pembelajaran kooperatif melalui media permainan ular tangga terhadap hasil belajar IPS siswa kelasIVdi SD Tembi Bantul tahun ajaran 2014/2015

\section{Pembahasan}

Dalam penelitian eksperimen ini, pembelajaran terhadap kedua kelompok dilakukan dengan cara yang berbeda. Kelompok pertama sebagai kelas eksperimen menggunakan metode pembelajaran kooperatif melalui media permainan ular tangga, sedangkan kelompok kedua sebagai kelas kontrol menggunakan metode pembelajaran konvensional. Untuk mengetahui tingkat penguasaan siswa terhadap materi pelajaran yang dalam pembelajaran dilakukan dengan cara yang berbeda, peneliti mengukurnya melalui hasil tes belajar siswa. Tes yang dilakukan ini sebanyak dua kali yaitu yang disebut pretest (tes sebelum proses pembelajaran) dan posttest (tes setelah proses pembelajaran).

Pembelajaran di kelas eksperimen mendapat perlakuan dengan menggunakan metode pembelajaran kooperatif melalui media permainan ular tangga. Pada proses pembelajaran siswa merasa senang dan antusias dalam mengikuti pembelajaran, hal ini dikarenakan siswa terlibat langsung dalam pembelajaran, siswa menjadi aktif dan kejenuhan dalam pembelajaran dapat dihilangkan. Pada pemebalajran ini materi yang disampaikan guru telah tersaji dalam permainan ular tangga dan siswa dapat menguasai materi dengan baik karena penyajian materi diberikan dengan metode permainan. Berdasarkan hasil penelitian, pada saat pengujian pretest siswa dikelas experimen mendapatkan nilai tertinggi 90, nilai terendah 55, dan rata-rata nilai pre-test sebesar 73,86. Sedangkan pada saat pengujian post-tes siswa dikelas experimen mendapatkan nilai tertinggi 100 , nilai terendah 70 , dan rata-rata nilai post-test sebesar 81,82. Hal ini telah menunjukkan bahwa setelah mendapatkan perlakuan dengan menggunakan metode pembelajaran kooperatif melalui media permainan ular tangga terdapat peningkatan hasil belajar siswa kelas IVdi SD Tembi.

Sedangkan pembelajaran yang dilakukan pada kelompok kontrol dengan menggunakan metode pembelajaran konvensional, penyampaian materi sepenuhnya berasal 
dari penjelasan guru dan siswa hanya mendengarkan penjelasan tersebut. Guru dalam pembelajaran banyak menggunakan ceramah, hal ini tidak menarik perhatian siswa dan kurang efektif dalam pembelajaran. Siswa kurang antusias dalam mempelajari materi tersebut, hanya terlihat siswa yang pandai saja yang terlihat aktif. Pada akhir pembelajaran juga diberi tes akhir seperti pada kelas eksperimen, akan tetapi hasil yang didapat oleh kelas kontrol tidak begitu memuaskan dan hanya siswa yang pandai saja yang mendapat nilai yang baik. Berdasarkan hasil penelitian, pada saat pengujian pre-test siswa dikelas kontrol mendapatkan nilai tertinggi 95, nilai terendah 60, dan rata-rata nilai pre-test sebesar 76,82. Sedangkan pada saat pengujian post-tes siswa dikelas kontrol mendapatkan nilai tertinggi 85 , nilai terendah 50 , dan rata-rata nilai post-test sebesar 66,82 . Hal ini menunjukkan pembelajaran dikelas kontrol dengan menggunakan metode konvensional kurang diminati oleh siswa.

Dari paparan diatas, pembelajaran yang menggunakan metode pembelajaran kooperatif melalui media permainan ular tangga lebih efektif dibandingkan dengan pembelajaran menggunakan metode konvensional. Terbukti dari hasil tes belajar siswa pada mata pelajaran IPS, siswa kelas eksperimen yang menggunakan metode pembelajaran kooperatif melalui media permainan ular tangga memiliki rata-rata nilai kelas yang lebih tinggi dibanding dengan nilai rata-rata siswa kelas kontrol yang menggunakan metode pembelajaran konvensional.

Berdasarkan hasil uji hipotesis yang telah dilakukan dapat diketahui bahwa $t_{\text {hitung }}=12,7754$ dan $t_{\text {tabel }}=2,0441$. Sehingga dapat disimpulkan bahwa penggunaan metode pembelajaran kooperatif melalui media permainan ular tangga berpengaruh terhadap hasil belajar IPS dengantaraf signifikansi 5\% atau 0,05. Hal ini semakin diperkuat dengan hasil belajar yang diperoleh pada kelas kontrol dan kelas eksperimen, yaitu untuk kelas kontrol dengan jumlah siswa 11 anak memiliki nilai rata-rata 66,82 . Sedangkan pada kelas ekperimen dengan jumlah siswa 22 anak memiliki nilai rata-rata 81,82 . Berdasarkan data tersebut terbukti bahwa pembelajaran di kelas ekperimen yang menggunakan metode pembelajaran kooperatif melalui media permainan ular tangga memiliki rata-rata yang lebih baik bila dibandingkan dengan kelas kontrol yang menggunakan metode pembelajaran konvensional.

Kesimpulan dari penelitian ini yaitu ada pengaruh yang signifikan penggunaan metode pembelajaran kooperatif melalui media permainan ular tangga terhadap hasil belajar IPS siswa kelas IV SD Tembi Bantul Tahun Pelajaran 2014/2015. 


\section{E. Penutup}

Dari analisis data dan pembahasan yang telah disampaikan dapat disimpulkan sebagai berikut:

1. Ada perbedaan hasil belajar siswa dengan menggunakan metode pembelajaran kooperatif melalui media permainan ular tangga dan hasil belajar siswa dengan menggunakan metode pembelajaran konvensional. Hal ini dapat dilihat dari rata-rata nilai kelas experimen lebih tinggi dibandingan dengan kelas kontrol yakni nilai rata-rata kelas experimen sebesar 81,82 dan nilai rata-rata kelas kontrol sebesar 66,82.

2. Berdasarkan hasil analisis data, diperoleh $t_{\text {hitung }}=12,7754$ dan $\mathrm{t}_{\text {tabel }}=2,0441$. Karena $\mathrm{t}_{\text {hitung }}>$ $\mathrm{t}_{\text {tabel}}$, maka Ha diterima dan Ho ditolak. Kesimpulannya bahwa ada pengaruh metode pembelajaran kooperatif melalui media permainan ular tangga terhadap hasil belajar IPS siswa kelasIVdi SD Tembi Bantul tahun ajaran 2014/2015

\section{Daftar Pustaka}

Agus Supijono. 2011. Cooperative Learning Teori dan Aplikasi PAIKEM. Yogyakarta: Pustaka Pelajar.
Asep Jihad dan Abdul Haris. (2008). Evaluasi Pembelajaran. Yogyakarta : Multipressindo

Arsyad, Azhar. 2002. Media Pembelajaran. Jakarta: Raja Grafindo Persada

Harjanto. 2005. Perencanaan Pengajaran. Jakarta: Rineka Cipta

Suwarna. 2005. Pengajaran Mikro. Yogyakarta: Tiara Wacana

Etin Solihatin dan Raharjo. 2007. Cooperative Analisis Model Pembelajaran IPS. Jakarta: Bumi Aksara

Isjoni. 2010. Cooperative Learning Mengembangkan Kemampuan Belajar Kelompok. Bandung: Alfabeta

Maya Kartika Sari. 2012. Pengenalan dan Pembelajaran IPS suatu Kajian Konsep Dasar IPS SD. Madiun : IKIP PGRI Madiun.

Sugiyono. 2007. Metode Penelitian Kuantitatif, Kualitatif dan $R \& D$. Bandung: Alfabeta

Suharsimi Arikunto. 2010. Prosedur Penelitian Suatu Pendekatan Praktik. Jakarta: Rineka Cipta

Maya Kartika. 2014. PengaruhMetodeKooperatif Jigsaw Terhadap Prestasi Belajar Mata Pelajaran IPS Pada Siswa Kelas III di SD Islamiyah Pakualaman. Premiere Educandum Jurnal Pendidikan Dasar dan Pembelajaran/Volume 4/Nomor 2/Desember 2014 
Trustho Raharjo. 2013. Pengembangan Media

Pembelajaran Fisika

Menggunakan Permainan

Ular Tangga Ditinjau Dari

Motivasi Belajar Siswa

Kelas Viii Materi Gaya.

Jurnal Pendidikan Fisika

(2013) Vol.1 No.1 halaman
18. ISSN. $2338-0691$.

Rahina Nugrahani. (2007). Media Pembelajaran Berbasis Visual Berbentuk Permainan Ular Tangga untuk Meningkatkan Kualitas Belajar Mengajar di Sekolah Dasar. Jurnal Kependidikan jilid 36, No. 1 